\title{
PENINGKATAN KETERAMPILAN IBU-IBU RUMAH TANGGA DALAM PEMBUATAN SALE PISANG DENGAN TEKNOLOGI PENGERING BIOMASSADI DESA PAKEMITAN,KEC. CIKATOMAS, KAB. TASIKMALAYA
}

\author{
Aripin, Sutisna, Muhammad Aris Risnandar \\ Jurusan Teknik Elektro, Fakultas Teknik, Universitas Siliwangi \\ aripin@unsil.ac.id
}

\begin{abstract}
The average banana production in Pakemitan Village is 9.2 tons/year. The jackfruit and ambon bananas dominate nearly $63.84 \%$ of the total banana production in Pakemitan Village. When the number of harvests increases, jackfruit and ambon bananas were not sold in the market. With abundant and cheap bananas, and unhygienic drying of sale bananas using sunlight, it is necessary to encourage housewives to convert bananas into sale bananas and drying them with biomass drying technology. The training implementation method starts from program socialization, theoretical training on making banana sale, preparation of tools and materials, and field practice of making banana sale and drying it with biomass dryer. The housewives who attended the training were 15 people. Housewives are informed about the procedure and practice of making banana sale and the process of drying banana sale. The results of the evaluation showed that over $80 \%$ of housewives were categorized as skilled participants in making banana sale and using biomass dryers. The results show that there is an increase in insight and knowledge of making banana sale using a biomass dryer, so participants can make banana sale independently.
\end{abstract}

Keywords: banana, sale banana, biomass drying, housewives

\begin{abstract}
Abstrak
Rata-rata produksi pisang di Desa Pakemitan adalah 9,2 ton/tahun. Produksi pisang nangka dan ambon mendominasi hampir 63,84\% dari total hasil produksi pisang di Desa Pakemitan. Ketika meningkatnya jumlah panen, pisang nangka dan ambon tidak laku dijual di pasar. Dengan melimpah dan murahnya buah pisang, serta pengeringan tidak higienis menggunakan cahaya matahari untuk pengeringan pisang sale, itu perlu mendorong ibu-ibu rumah tangga untuk merubah buah pisang menjadi pisang sale dan pengeringannya dengan teknologi pengering biomassa. Metode pelaksanaan pelatihan dimulai dari sosialisasi program, pelatihan teoritis pembuatan pisang sale, penyiapan alat dan bahan, dan praktek lapangan pembuatan sale pisang dan pengeringannya dengan pengering biomassa. Para ibu-ibu rumah tangga yang hadir dalam pelatihan ini adalah 15 orang. Metode praktek dilakukan dengan mempraktekan langsung penggunaan mesin pengering biomassa dan pembuatan pisang sale. Ibu-ibu dibelaki tatacara dan praktek pembuatan sale pisang dan proses pengeringan sale pisang. Hasil evaluasi kegiatan pada penyerapan materi pelatihan menunjukkan bahwa di atas $80 \%$ dari jumlah peserta sudah dikatagorikan terampil sangat baik dalam pembuatan pisang sale. Hasil yang dicapai menunjukkan bahwa terdapat peningkatan wawasan dan pengetahuan pembuatan pisang sale menggunakan pengering biomassa, sehingga peserta dapat membuat sale pisang secara mandiri tanpa bantuan pendampingan.
\end{abstract}

Kata Kunci: buah pisang, pisang sale, pengering biomassa, ibu-ibu rumah tangga 


\section{Pendahuluan}

Desa Pakemitan adalah salah satu desa yang terletak di Kec. Cikatomas, Kab. Tasikmalaya dengan jumlah penduduk 6.198 jiwa dengan mayoritas penduduknya memiliki mata pencaharian sebagai petani (BPS Kab. Tasikmalaya, 2018). Luas wilayah Desa Pakemitan adalah $1.248 \mathrm{Ha}$ dan sebagian besar merupakan lahan pesawahan, perkebunan kelapa dan pisang. Dari seluruh areal perkebunan pisang, pohon pisang tumbuh dalam bentuk hamparan perkebunan yang dipelihara masyarakat. Hampir semua kepala keluarga memiliki tanaman pisang, paling tidak ditanam di halaman pekarangan rumah. Jenis pisang yang banyak ditanam masyarakat meliputi pisang nangka, pisang raja bulu, pisang ambon, pisang kapas dan pisang lampeneng. Rata-rata hasil produksi buah pisang di Desa Pakemitan adalah 9,2 ton/tahun. Produksi buah pisang nangka dan ambon mendominasi hampir $63,84 \%$ dari total hasil produksi buah pisang di Desa Pakemitan. Biasanya hasil panen buah pisang tersebut dikonsumsi sendiri oleh masyarakat, dijual dalam bentuk tanpa olahan dan dijual dalam bentuk olahan, misalnya pisang goreng, keripik pisang, pisang sale dan lain - lain. Petani pada umumnya menjual buah pisang tanpa olahan ke para pembeli/bandar dengan harga bervariasi satu sama lain tergantung pada tingkatan mutu dan jenis pisangnya. Pisang raja bulu, kapas dan lampeneng mempunyai harga yang bersaing di pasaran dengan harga Rp. $7.000 ., / \mathrm{kg}$, sedangkan pisang nangka dan ambon mempunyai harga yang paling murah dengan harga mencapai Rp. 2.500,-/kg, bahkan ketika meningkatnya jumlah panen, pisang nangka dan ambon tidak laku dijual ke para pembeli.

Desa Pakemitan terdapat organisasi/kelompok ibu-ibu rumah tangga dalam jamaah pengajian DKM Al-Huda dan DKM Al-Gofur sebagai pengrajin pisang sale. Rata-rata ibu-ibu rumah tangga jamaah pengajian mempunyai kegiatan membuat sale pisang dari pisangpisang yang tidak laku dijual. Pisang yang dibuat untuk sale biasanya dikeringkan menggunakan cahaya matahari sampai kadar airnya mencapai kadar air persyaratan maksimal SNI 40\% (BSN, 1996). Proses pengeringan sale pisang dengan cahaya matahari tidak terjadi secara higienis karena ada volatile matter dan debu yang tertiup dan mengenai sale pisang yang dikeringkan. Ini akan mempengaruhi pada mutu sale pisang yang dihasilkan (Fery, 2016 dan Marwati, 2017). Berdasarkan analisis potensi melimpahnya produksi buah pisang di Desa Pakemitan dan adanya kegiatan ibu-ibu rumah tangga dalam pembuatan sale pisang, maka itu perlu mendorong ibu-ibu rumah tangga untuk mengolah buah pisang menjadi produk olahan sale pisang yang mempunyai nilai jual lebih tinggi dari buah pisang menggunakan pengering biomassa. Pengeringan serupa telah dikerjakan menggunakan alat pengering otomatis (Budihartanto, 2007), Atas dasar analisa situasi yang diuraikan di atas, maka masalah prioritas yang perlu ditangani melalui kegiatan pengabdian ini adalah:

a. Harga buah pisang sangat fluktuatif. Pada saat musim panen raya hasil buah pisang melimpah di pasaran sehingga harga buah pisang terutama jenis pisang nangka dan ambon dapat turun drastis.

b. Buah pisang memiliki daya simpan yang tidak lama (sekitar 2 minggu). Buah pisang yang disimpan lebih dari waktu itu akan membusuk. 
c. Proses pengeringan pisang sale dengan cahaya matahari tidak terjadi secara higienis karena ada volatile matter dan debu yang tertiup dan mengenai pisang sale yang dikeringkan.

d. Terbatasnya kemampuan (pengetahuan dan ketrampilan) pengrajin pisang sale dalam mengeringkan produk pisang sale berkualitas.

Tujuan kegiatan pengabdian ini adalah:

a. Meningkatkan nilai tambah buah piang menjadi sale pisang.

b. Meningkatkan keterampilan dan pengetahuan ibu-ibu rumah tangga dalam pembuatan sale pisang dengan teknologi pengering biomassa.

\section{Metode Kegiatan}

\section{Kegiatan Persiapan}

Kegiatan dirancang melalui pertemuan dan komunikasi dengan ketua DKM Al-Ihsan dan "DKM Al-Gofur di Desa Pakemitan untuk meminta izin kegiatan pengabdian tentang peningkatan keterampilan ibu-ibu rumah tangga pada kelompok pengajian di "DKM AlIhsan" dan "DKM Al-Gofur. Selanjutnya itu juga didiskusikan tentang tempat dan waktu kegiatan, jumlah peserta, undangan peserta, bahan dan alat yang diperlukan untuk kegiatan pelatihan. Waktu yang disepakati untuk kegiatan adalah tanggal 20 dan 21 Juli 2019.

\section{Pelaksanaan Kegiatan}

Pelaksanaaan kegiatan pembuatan pisang sale diberikan kepada 15 orang dari Kelompok pengajian ibu-ibu "DKM Al-Ihsan" dan "DKM Al-Gofur, di Desa Pakemitan, Kec. Cikatomas, Kab. Tasikmalaya. Pelaksanaan kegiatan ini menggunakan metode pelatihan dan metode praktek (learning by doing) dengan memberikan praktek pembuatan sale pisang dang pengeringan sale pisang menggunakan pengering biomassa. Secara garis besar tahapan-tahapan kegiatan pelatihan pembuatan sale pisang dan pengeringannya dengan pengering biomassa adalah sebagai berikut:

a. Penyampaian program pengabdian kepada masyarakat dalam bentuk pelatihan pembuatan sale pisang dan pengeringannya.

b. Penyampaian potensi buah pisang dan alternatif-alternatif untuk mengatasi melimpah dan murahnya harga pisang.

c. Penyampaian strategi bisnis buah pisang dan alternatifnya.

d. Penyampaian cara pembuatan sale pisang nangka dan ambon.

e. Penyampaian cara mengeringkan sale pisang dengan pengering bimassa dan kelemahannya.

f. Praktek pembuatan sale pisang.

g. Praktek pengeringan sale pisang menggunakan pengering biomassa.

3. Pendampingan

Kegiatan pendampingan ibu-ibu rumah tangga dalam pembuatan sale pisang dan pengeringannya dilakukan dengan menempatkan pendamping secara periodik untuk memantau kegiatan mitra dan memberikan solusi atas permasalahan teknik produksi yang terjadi. Waktu pendampingan adalah tanggal 18 Agustus 2019 dan 8 September 2019.

4. Monitoring dan Evaluasi 
Proses monitoring dan evaluasi secara periodik akan dilakukan sampai kelompok mitra bisa mandiri dalam menghasilkan produk pisang sale dan menjalankan usahanya secara berkelanjutan sehingga secara keseluruhan tujuan, target dan luaran kegiatan dapat tercapai dengan baik. Tabel 1 menunjukkan instrumen monitoring dan evaluasi pengabdian kepada masyarakat.

Tabel 1. Instrumen Monev Setelah Pelatihan Pembuatan Sale Pisang

\begin{tabular}{cl}
\hline No & \multicolumn{1}{c}{ Item pertanyaan } \\
\hline 1 & Peserta membuat pisang sale tanpa cacat \\
\hline 2 & Peserta trampil menggunakan mesin pengering \\
\hline 3 & Peserta trampil mengeringkan pisang sale \\
\hline 4 & Peserta trampil mengatur pengeringan pisang sale \\
\hline 5 & Peserta membuat 40 kemasan pisang sale dalam satu hari \\
\hline 6 & Peserta membuat pisang sale berkadar air kurang 40\% (Standar SNI) \\
\hline
\end{tabular}

\section{Hasil dan Pembahasan}

Kegiatan pengabdian ini dilakukan melalui pelatihan dan praktek pembuatan pisang sale di Desa Pakemitan, Kec. Cikatomas, Kabupaten Tasikmalaya. Pelatihan dan praktek dilaksanakan pada hari Sabtu, 20 Juli 2019 sampai Minggu, 21 Juli 2019 di Desa Pekemitan, Kec. Cikatomas, Kab. Tasikmalaya. Para peserta yang hadir dalam kegiatan tersebut sebanyak 15 orang dari kelompok taruna DKM Al-Huda dan Al-Gofur.

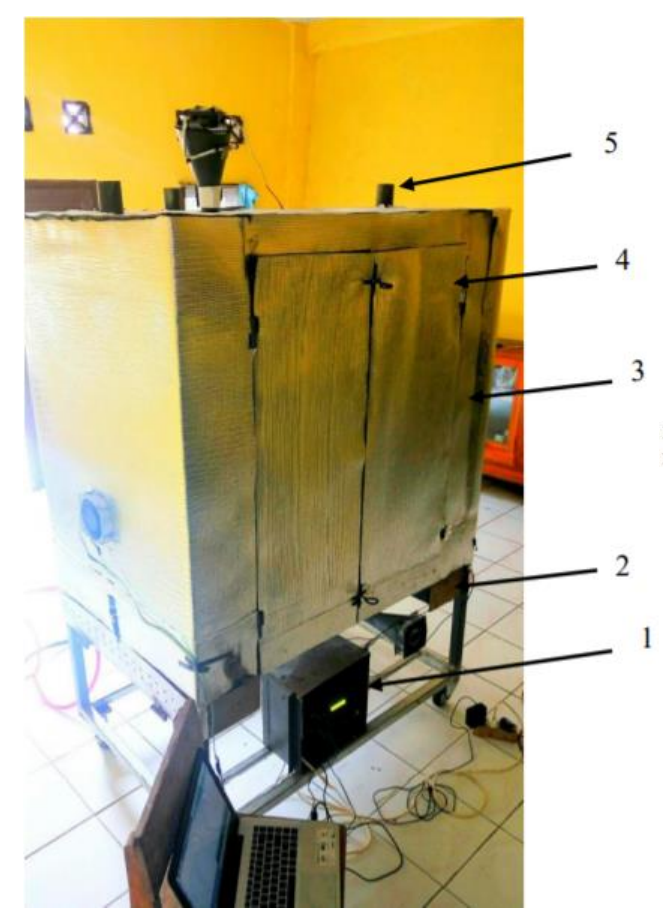

(a)

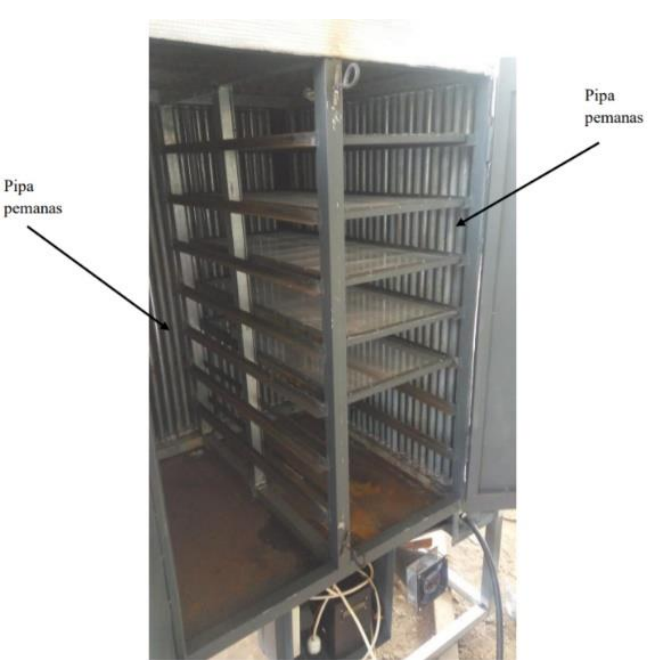

(b)

Gambar 1. (a) Pengering biomassa (tampak depan) dengan komponen (1) panel kontrol temperatur, (2) ruang tungku pembakaran, (3) ruang pipa pemanas, (4) rak pengering, (5) ruang pengeluaran asap, dan (b) Pengering biomassa (tampak dalam). 


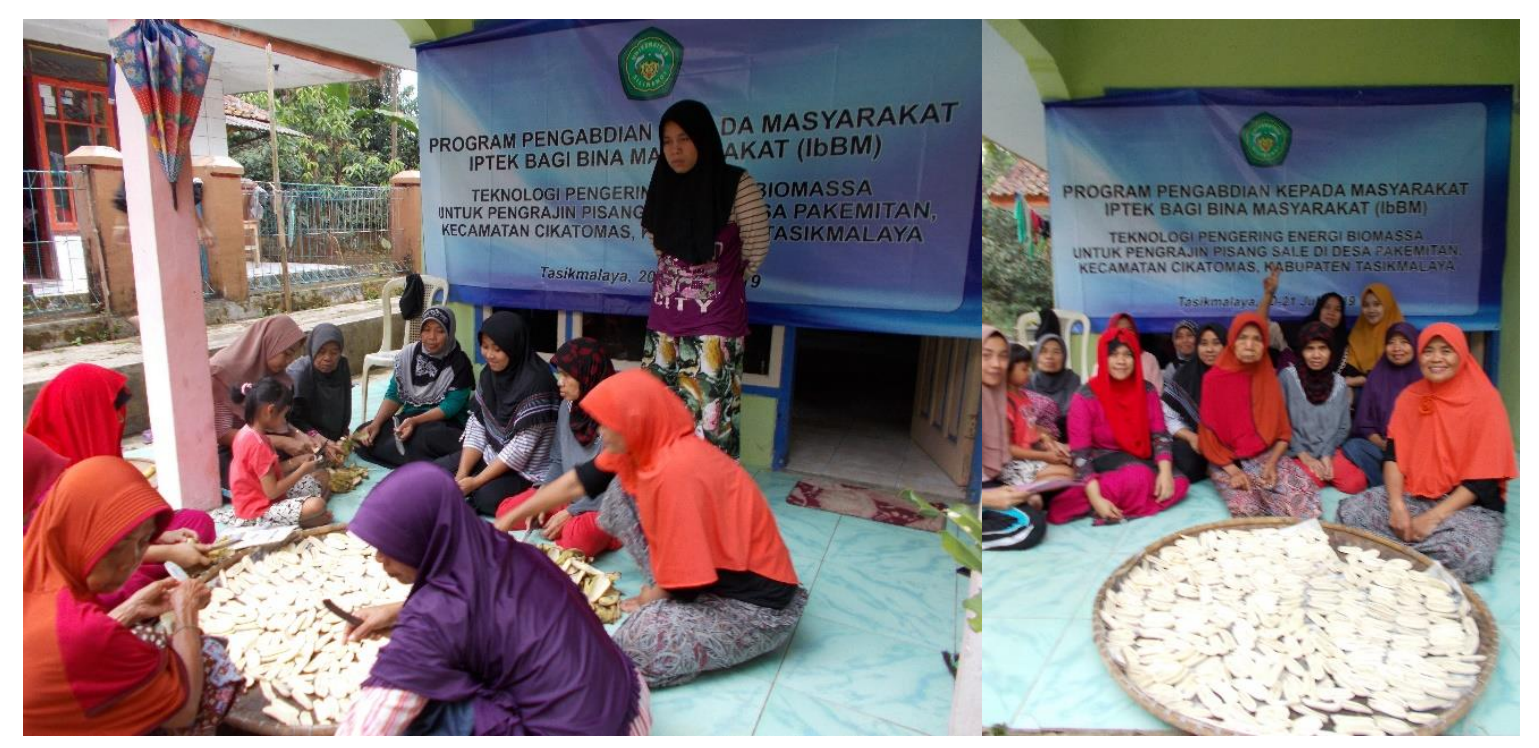

Gambar 2. Pembuatan Sale Pisang

Gambar 1 menunjukkan pengering biomassa untuk mengeringkan sale pisang. Alat ini merupakan pengembangan dari alat pengering kelom geulis (Edvin, 2016). Alat pengering sale pisang terdiri dari lima bagian yaitu ruang tungku pemanas, dua ruang pipa heat exchanger, ruang rak pengering dan ruang pengeluaran asap dari pipa. Rak pengering merupakan tempat dimana sale pisang yang dikeringkan ditempatkan. Rak pengering ini terbuat dari rangka besi berukuran $80 \mathrm{~cm}$ x $80 \mathrm{~cm}$ x $90 \mathrm{~cm}$ dengan tiap lapisan rak yang tersusun berjarak $12 \mathrm{~cm}$. Dalam tiap susunan rak, terdapat lembaran tempat menaruh sale pisang yang dikeringkan yang terbuat dari kawat kasa yang dapat ditarik keluar berukuran lubang $1 \mathrm{~cm} \times 1 \mathrm{~cm}$. Pengontrol temperatur otomatis merupakan sensor temperatur yang dipasang pada ruang pengeringan. Temperatur diatur sesuai dengan kebutuhan dengan cara mengatur masukan bahan bakar biomassa pada ruang tungku pembakaran. Temperatur pengeringan terukur untuk sale pisang adalah dalam rentang $55-70 \mathrm{oC}$ selama 6 jam dan menghasilkan kadar air sale pisang antara $32-38 \%$. Pengeringan ini menghasilkan kadar air yang memenuhi persyaratan SNI dan sesuai dengan hasil pengeringan yang telah dilakukan sebelumnya (Taiwo, 2009; Rahman, 2017; Harianto, 2018).

Gambar 2 menunjukkan kegiatan pelatihan membuat sale pisang. Kegiatan pengabdian ini dilakukan melalui pelatihan dan praktek pembuatan sale pisang dan proses pengeringan menggunakan pengering biomassa di Desa Pakemitan, Kec. Cikatomas, Kabupaten Tasikmalaya. Pelatihan dan praktek dilaksanakan pada hari Sabtu, 20 Juli 2019 sampai Minggu, 21 Juli 2019. Para ibu-ibu rumah tangga yang hadir dalam kegiatan tersebut sebanyak 15 orang dari kelompok pengajian "DKM Al-Ihsan" dan "DKM Al-Gofur, di Desa Pakemitan, Kec. Cikatomas, Kab. Tasikmalaya. 
Aripin, Sutisna, Risnandar, Peningkatan Keterampilan Ibu-Ibu Rumah Tangga...

Tabel 2. Hasil Pelatihan Pembuatan Sale Pisang

\begin{tabular}{lcc}
\hline \multicolumn{1}{c}{ Item pertanyaan } & Prosentase & Kategori \\
\hline Peserta trampil menggunakan mesin pengering & 83,12 & Sangat baik \\
\hline Peserta trampil mengeringkan pisang sale & 86,67 & Sangat baik \\
\hline Peserta trampil mengatur pengeringan pisang sale & 82,41 & Sangat baik \\
\hline Peserta membuat pisang sale tanpa cacat & 84,12 & Sangat baik \\
\hline $\begin{array}{l}\text { Peserta membuat 40 kemasan pisang sale dalam satu } \\
\text { hari }\end{array}$ & 80,65 & Sangat baik \\
\hline $\begin{array}{l}\text { Peserta membuat pisang sale berkadar air kurang 40\% } \\
\text { (Standar SNI) }\end{array}$ & 83,17 & Sangat Baik \\
\hline
\end{tabular}

Berdasarkan data ketercapaian pelatihan pembuatan sale pisang pada Tabel 2, itu menunjukkan bahwa jumlah peserta terampil berada di atas $80 \%$ dari peserta keseluruhan pada berbagai katagori keterampilan dalam pembuatan pisang sale. Secara umum, hal ini berarti bahwa ketercapaian kegiatan ini berkatagori sangat baik. Hasil yang dicapai menunjukkan bahwa peserta pelatihan sudah mampu mempraktekan sendiri wawasan dan keterampilan yang diperoleh selama pelatihan.

Selama berlangsungnya acara penyuluhan dan pelatihan, para peserta cukup antusias mengikuti materi yang disampaikan oleh pemateri dari dalam dan luar Universitas Siliwangi. Demikian halnya pada kegiatan praktek, partisipasi para peserta sangat dominan, sehingga dapat diprediksi bahwa tingkat serapan terhadap materi sangat baik.

Selanjutnya, pemberdayaan ibu-ibu rumah tangga melalui pelatihan pembuatan sale pisang dan pengeringannya ini mempunyai potensi pengembangan bisnis yang tinggi. Setelah sale pisang diproduksi, itu bisa dipasarkan sebagai sebagai sale pisang tanpa goreng oleh-oleh khas Tasikmalaya. Produksi sale pisang ini akan terus menerus karena bahan baku buah pisang akan berlimpah jika budi daya pisang terus dilakukan oleh masyarakat lokal.

\section{Kesimpulan}

a. Hasil evaluasi kegiatan pada penyerapan materi pelatihan menunjukkan bahwa di atas $80 \%$ ibu-ibu rumah tangga sudah dikatagorikan terampil sangat baik dalam pembuatan sale pisang.

b. Hasil pengujian parameter kadar air pisang sale yang dibuat oleh peserta sudah sesuai dengan standar SNI.

c. Hasil yang dicapai menunjukkan bahwa peserta pelatihan sudah mampu mempraktekan sendiri wawasan dan keterampilan yang diperoleh selama pelatihan, sehingga peserta dapat membuat sale pisang secara mandiri tanpa bantuan pendampingan.

\section{Ucapan Terima Kasih}

Penulis mengucapkan terima kasih kepada Universitas Siliwangi yang telah mendanai kegiatan pengabdian kepada masyarakat melalui Ipteks bagi Bina Masyarakat (IbBM) Tahun 2019. Di samping itu, penulis juga ingin mengucapkan banyak terima kasih kepada Bapak Aep dan Rukman dari DKM Al-Ihsan" dan "DKM Al-Gofur, di Desa Pakemitan, Kec. Cikatomas, Kab. Tasikmalaya. 


\section{Daftar Pustaka}

BPS Kabupaten Tasikmalaya, 2018. Badan Pusat Statistik Kabupaten Tasikmalaya.

BSN (Badan Standardisasi Nasional) 1996. Standar Nasional Indonesia: Syarat Mutu Sale Pisang (SNI 01-4319-1996). Jakarta: Badan Standardisasi Nasional.

Budihartanto, A., Satyoadi, M., 2007. Alat Pengering Pisang Menjadi Sale Berbasismikrokontroler, Widya Teknik Vol. 6 No. 1, hal. 42-55.

Edvin P., Maftuh, A., Sujudi, 2016. Pengembangan Sistem Pengering Kelom Geulis Berbasis Mikrokontroler Dengan Dua Sisi Berpemanas Pipa, Jurnal Teknologi, Vol. 9 No. 2, hal. $172-176$

Fery, I.D, 2016. Pengaruh Teknik Pengeringan Terhadap Kadar Gizi Dan Mutu Organoleptik Sale Pisang (Musa paradisiacaL.), Jurnal Farmasi, Vol. 4, hal. 23 - 28.

Harianto, J., Aziz, A., 2018. Analisis Pompa Kalor Siklus Udara Tertutup Untuk Pengeringan Pisang, Jom FTEKNIK Vol. 5, hal. 1 - 8.

Marwati, Y., Yulian, A., Mentari, 2017. Pengaruh Suhu Dan Lama Pengeringan Terhadap Sifat Kimia Dan Organoleptik Sale Pisang Kapas (Musa Comiculata), Jurnal Kimia Mulawarman, Vol. 15, hal. $22-26$.

Rahman, A.F., Sukmawaty, Sabani, R, 2017. Evaluasi Pengeringan Pisang Sale (Musa paradisiaca L.) Pada Alat Pengering Hybrid (Surya-Listrik) Tipe Rak, Jurnal Ilmiah Rekayasa Pertanian dan Biosistem, Vol.5, No. 1, hal. 360 - 368.

Taiwo, K.A dan dan. Adeyemi, O. 2009. Influence of Blanching on The Drying and Rehydration of Banana Slices. African Journal of Food Science Vol.3 No.2, hal 307315. 